\title{
IMIGRANCI W POLSKIEJ PRZESTRZENI WIELKOMIEJSKIEJ. PRZYPADEK POZNANIA ${ }^{1}$
}

\begin{abstract}
Schmidt Jacek, Imigranci w polskiej przestrzeni wielkomiejskiej. Przypadek Poznania [Immigrants in the Polish city. The case of Poznań] edited by J. Kubera, Ł. Skoczylas - „Człowiek i Społeczeństwo", vol. XXXVII, Poznań 2014, pp. 53-62, Adam Mickiewicz University Press. ISBN 978-83232-2764-9. ISSN 0239-3271.

Immigrants make up only $2 \%$ of the total population in Poland. Over $80 \%$ of such immigrants reside in cities. Poland is only a transit point in their migration to the West or a temporary place of work or education. The paper focuses on the structure of the several-thousand, heterogeneous immigrant population in Poznań and the institutions within which they function and pursue their particular adaptation and integration strategies. Foreigners in Poznań live to some extent "next to" the receiving society and are hardly visible in the city space. Their migration is circular and often seasonal. A significant percentage is made up of the so called privileged migrants (students obliged to pay tuition fees at public and private universities and business professionals). Poznań, which is not a multicultural city, is not an important centre in the transnational network and can be defined as a typical "national" city based on local forms of socio-cultural relations.
\end{abstract}

Jacek Schmidt, Uniwersytet im. Adama Mickiewicza w Poznaniu, Centrum Badań Migracyjnych, ul. Św. Marcin 78, 61-809 Poznań, Poland.

Przedmiotem rozważań podjętych w artykule jest opis i analiza funkcjonowania cudzoziemców w Poznaniu - ich heterogeniczności kulturowej, strategii adaptacyjno-integracyjnych oraz budowanych sieci i pól powiązań transnarodowych (Faist 2010). Temat ten wymaga wprowadzenia, w formie krótkiej charakterystyki, specyfiki zjawiska imigracji w Polsce.

1 Treść artykułu oparta jest na wynikach badań przeprowadzonych w latach 2009-2012, w ramach projektu badawczego NCN nr NN 109224836 Cudzoziemcy w Polsce. Heterogeniczność kulturowa ośrodków wielkomiejskich na przykładzie Poznania, kierowanego przez prof. dr. hab. Michała Buchowskiego. Najważniejszym rezultatem tych pogłębionych jakościowych badań jest obszerna monografia (Buchowski, Schmidt (red.) 2012), a w przygotowaniu znajduje się kolejny zbiór tekstów poświęconych analizie środowiska imigrantów w Poznaniu z perspektywy makroanalitycznej. 
W wyniku zmiany granic oraz powiązanych z tym przesunięć ludnościowych po II wojnie światowej Polska stała się największym „monolitem” etnicznym Europy i takim pozostaje do chwili obecnej². Według danych najnowszego Narodowego Spisu Powszechnego (2011) w naszym kraju przebywa czasowo zaledwie 56,3 tys. cudzoziemców, w tym 29 tys. osób, które mają ponadroczny staż pobytowy ${ }^{3}$. Jednak dane te nie odzwierciedlają stanu faktycznego - są dalece zaniżone, ponieważ nie obejmują cudzoziemców o nieuregulowanym statusie pobytu, części imigrantów legitymujących się obywatelstwem innych krajów Unii Europejskiej, a także osób, które $\mathrm{z}$ różnych powodów nie uczestniczyły w procedurze spisowej (Kaczmarczyk 2011: 14-18). Szacunki podane przez Główny Urząd Statystyczny mówią już o 380 tys. cudzoziemców w Polsce (Wspótpraca... 2012: 9), a eksperci zagraniczni twierdzą, iż w 2005 roku była to grupa licząca ponad 700 tys. osób (Alscher 2008: 3-4). Liczby te dokumentują fakt, że imigracja w Polsce na tle innych krajów europejskich, gdzie mamy do czynienia z procentem imigrantów wahającym się średnio od $5 \%$ do $20 \%$, jest mało znaczącym zjawiskiem demograficznym (Buchowski, Schmidt 2012: 9-10). Jednocześnie gdy zestawimy tylko same dane ze źródeł rejestrowych, to uwidaczniają one umiarkowaną dynamikę zjawiska imigracji, czyli dwukrotny wzrost liczby cudzoziemców w naszym kraju w ostatniej dekadzie (2002-2011).

W świetle niereprezentatywnych dla przedmiotowej populacji danych ze źródeł rejestrowych wynika, że 78\% imigrantów w Polsce stanowią cudzoziemcy, a 22\% Polacy, którzy mieszkają na stałe $\mathrm{w}$ innych państwach, będących tradycyjnie lub $\mathrm{w}$ ostatnim czasie głównym miejscem emigrowania (Niemcy, Wielka Brytania, Stany Zjednoczone, Włochy, Francja i Irlandia). W tym pierwszym przypadku głównym powodem imigrowania jest praca, a w drugim - sprawy rodzinne. Imigranci przebywający w Polsce są zbiorowością ludzi młodych - połowa z nich ma mniej niż 28 lat, a co piąty jest w wieku 20-24 lata; 70\% z nich jest w wieku produkcyjnym.

Rozmieszczenie imigrantów na terenie kraju jest nierównomierne. Blisko jedna trzecia $\mathrm{z}$ nich przebywa $\mathrm{w}$ województwie mazowieckim, ze szczególną koncentracją $\mathrm{w}$ Warszawie, natomiast $\mathrm{w}$ kilku innych województwach (dolnośląskie, małopolskie, śląskie, łódzkie, pomorskie, wielkopolskie i lubu-

${ }^{2}$ Członkowie mniejszości narodowych (9) i etnicznych (4) w Polsce - obywatele polscy spełniający kryteria Ustawy z dnia 6 stycznia 2005 r. o mniejszościach narodowych i etnicznych oraz języku regionalnym (Dz. U. 2005 Nr 17, poz. 141) - nie będą przedmiotem rozważań w tym tekście. Ich liczebność, między innymi ze względu na różną metodologię przyjętą w kolejnych spisach powszechnych, jest trudna do ustalenia, niemniej można przyjęć, iż nie stanowią oni więcej niż $5 \%$ obywateli polskich.

${ }^{3}$ http://tuudi.net/wp-content/uploads/2012/08/lu_raport_z_wynikow_NSP2011.pdf [dostęp: 1.10.2013]. 
skie) stanowią każdorazowo od około $6 \%$ do $9 \%$ omawianej zbiorowości. Z punktu widzenia prowadzonych $w$ artykule rozważań najistotniejsze jest jednak to, że ponad 80\% cudzoziemców żyje w wielkich miastach: Warszawie, Wrocławiu, Krakowie, Łodzi czy Poznaniu.

Polska wciąż pozostaje mało atrakcyjnym krajem dla migrantów, jawi się przede wszystkim jako punkt tranzytowy w dalszej wędrówce do zamożniejszych państw Zachodu lub tymczasowe miejsce pracy czy edukacji. Wielkie polskie miasta $\mathrm{w}$ niczym nie przypominają miast światowych $\mathrm{z}$ charakterystyki Ulfa Hannerza (2006: 191-208). W związku z tym, że nie są wielokulturowe, nie pełnią roli istotnych węzłów w sieci pól i powiązań transnarodowych, a ich organizacja kulturowa jest przede wszystkim związana z lokalnymi relacjami - można je postrzegać jako miasta "narodowe”. Trudno też mówić o jakiejkolwiek rywalizacji między społecznością przyjmującą a cudzoziemcami na rynku pracy, w sferze socjalnej i innych dziedzinach życia społecznego, zaś relatywnie nieliczne konflikty interetniczne, które dotykają imigrantów, mają zwykle charakter lokalny, często wynikają z ksenofobicznych, rasistowskich czy skrajnie nacjonalistycznych postaw niektórych obywateli polskich, noszą znamiona wybryków chuligańskich, czy wręcz zachowań przestępczych ${ }^{4}$.

Z rozproszonych danych urzędowych ${ }^{5}$ wynika, że w Poznaniu przebywa co najmniej 4,5 tys. imigrantów. Jednak, tak jak w przypadku ogólnopolskich źródeł rejestrowych, mamy do czynienia z nieodzwierciedlającymi rzeczywistość statystykami, które mogą nawet dwukrotnie zaniżać liczbę cudzoziemców przebywających w mieście. Znaczącą grupę (kategorię) w zbiorowości imigrantów w Poznaniu stanowią osoby przebywające w tym mieście na długoterminowych ${ }^{6}$ studiach. Ich status jest zróżnicowany.

\footnotetext{
${ }^{4}$ Dobrymi tego przykładami są wydarzenia z 2013 roku: napad na bar prowadzony przez Kurdów w centrum Opola oraz pobicie młodego Czeczena w białostockim autobusie (zob. http://wiadomosci.gazeta.pl/wiadomosci/1,114871,13828434,Pod_sad_za_atak_na_bar_Kurd ow_w_Opolu.html [dostęp: 1.10.2013]; http://wiadomosci.onet.pl/bialystok/napad-namlodego-czeczena-w-autobusie-rusza-proces/5et3z [dostęp: 30.10.2013].

${ }^{5}$ Dane gromadzone przez Wielkopolski Urząd Wojewódzki, które dotyczą pozwoleń na pobyt oraz wykonywanie działań zawodowych, nie wyodrębniają informacji o samym mieście. Z kolei zasoby źródłowe, jakimi dysponuje Urząd Miasta Poznania, są rozproszone po różnych wydziałach i często zawierają sprzeczne ze sobą informacje (zob. Bloch, Czerniejewska, Main 2012)

${ }_{6}$ Poza oglądem pozostawiam kilkusetosobową grupę studentów z zagranicy odbywających kilkumiesięczne, głównie semestralne studia w ramach programu Erasmus. Warto jednak zaznaczyć, że w ostatnich latach w tej zbiorowości najliczniej reprezentowani są cudzoziemcy z Turcji i Hiszpanii (Mirgos 2010: 66). Dane z pierwszej dekady stulecia oraz charakterystykę imigracji krótkoterminowej studentów można znaleźć w raporcie 7.8 ACRE, autorstwa zespołu poznańskich geografów (zob. http://dare.uva.nl/document/189079 [dostęp: 1.02.2014]).
} 
Dominują (ponad 60\% omawianej grupy - 1044 osoby w 2011 roku) studenci Uniwersytetu Medycznego im. Karola Marcinkowskiego, którzy odbywają płatne, sześcioletnie, czteroletnie lub dwuletnie, anglojęzyczne studia z zakresu medycyny, stomatologii lub fizjoterapii. Najliczniej w tej grupie reprezentowani są: Amerykanie, Norwegowie i Tajwańczycy, a w dalszej kolejności Szwedzi, Brytyjczycy i Niemcy. Drugą, umowną, grupę tworzą zagraniczni studenci długoterminowi na Uniwersytecie im. Adama Mickiewicza oraz kilkunastu innych, publicznych i niepublicznych, uczelniach poznańskich. Są oni rozproszeni po wszystkich wydziałach i studiują kilkadziesiąt kierunków. Najwięcej z nich pochodzi z krajów powstałych po rozpadzie Związku Sowieckiego - Białorusi, Ukrainy, Kazachstanu czy Rosji (około 300 osób), a także Niemiec i Chin. Osoby z zagranicy studiujące w Poznaniu w ramach studiów długoterminowych pochodzą z siedemdziesięciu państw. Tym, co wyróżnia Poznań na tle innych ośrodków, jest dominacja studentów anglojęzycznych studiów płatnych oraz obecność dużej grupy z Tajwanu, liczącej około 260 osób (Bloch, Czerniejewska, Main 2012: 72-75)

Drugą kategorię cudzoziemców rezydujących w Poznaniu tworzą profesjonaliści w sektorze biznesu. Są to imigranci pracujący na kierowniczych stanowiskach wysokiego i średniego szczebla w dużych korporacjach, takich jak np.: Volkswagen, Bridgestone, GlaxoSmithKline. $W$ tej grupie przeważają mężczyźni, którzy znaleźli się w Poznaniu w związku z atrakcyjną ofertą pracy i zwykle pozostają tu tylko przez czas określony w kontrakcie, wynoszący średnio trzy lata. Jeśli mają rodzinę, to przyjeżdżają do Poznania wraz z nią, a dzieci zapisują do anglojęzycznych placówek oświatowych (Czerniejewska 2010). Ich żony nie pracują zawodowo, zajmują się domem i dziećmi. Autonomiczną podkategorię wśród profesjonalistów w omawianym sektorze tworzą przedsiębiorcy prowadzący własne, zwykle małe lub średnie firmy. Są imigrantami o dłuższym, wynoszącym kilka bądź nawet kilkanaście lat, stażu pobytowym. Dominują wśród nich restauratorzy, właściciele sklepów lub firm handlowych, których działalność - oferowanie potraw kuchni narodowych lub obrót towarami regionalnymi - bywa często związana z krajem pochodzenia. Ludzie ci legitymują się dobrą znajomością języka polskiego, istotną $w$ ich środowisku zawodowym, często mają partnera życiowego, który jest Polką lub Polakiem. Ich przyjazd do Polski często nie wiązał się z obecnie wykonywaną pracą, wynikał z innych motywacji (np. studia lub polski partner) (Schmidt, Sydow 2012: 81-82, 94-97).

Trzecią kategorię stanowią profesjonaliści w sektorze edukacji - nauczyciele i lektorzy akademiccy oraz native speakerzy pracujący w szkołach językowych. Jest to bardzo zróżnicowana kulturowo, przypuszczalnie licząca około 200 osób, grupa imigrantów przybyłych z kilkudziesięciu państw zlo- 
kalizowanych na wszystkich kontynentach. Jest to także grupa bardzo zróżnicowana zarówno pod względem stażu pobytowego w Poznaniu, poziomu i profilu wykształcenia, jak i formy zatrudnienia. Część z tych imigrantów ma polskich partnerów, wielu pozostaje $\mathrm{w}$ związkach $\mathrm{z}$ osobami z krajów trzecich. Większość z nich, niezależnie od długości przebywania w Poznaniu i poczynionych tu inwestycji (np. kupno mieszkania czy domu), akcentuje tymczasowość pobytu w tym mieście (Bloch 2012; Jur 2012).

Czwartą kategorią są imigranci zarobkowi, którzy niezależnie od wykształcenia świadczą legalnie lub nielegalnie swe usługi w różnych dziedzinach działalności gospodarczej (budownictwo, pomoc domowa, handel uliczny) oraz tzw. szarej strefie (np. prostytucja, żebractwo, dilerka, nielegalny handel, praca "na czarno"). Z oczywistych powodów jest to zbiorowość imigrancka, która tylko w wybranych aspektach jest dostępna poznaniu naukowemu. W związku $\mathrm{z}$ tym badaniami $\mathrm{w}$ formie studiów przypadku objęto jedynie imigrantów pracujących na bazarach i w branży gastronomicznej (Adamowicz, Bloch, Kochaniewicz, Rydzewski, 2012: 99-129; Kochaniewicz 2013) oraz Romów z Rumunii (Chwieduk 2012: 235-248). Na tej podstawie można stwierdzić, iż nie są to liczne i zróżnicowane kulturowo grupy, jak to ma miejsce w Warszawie (Górny, Grabowska-Lusińska, Lesińska, Okólski (red.) 2010; Grzymała-Kazłowska 2008), nie tworzą niszy ani enklaw etnicznych, prowadzą głównie handlową działalność detaliczną, a sfera ich usług gastronomicznych nie przybiera charakteru sieciowego. W branży handlowej najliczniej reprezentowani są Bułgarzy, Ormianie, a następnie Ukraińcy, Gruzini, Litwini i Rumuni. Z kolei w sektorze gastronomicznym dominują Turcy i Chińczycy.

Piątą, prawdopodobnie najbardziej zróżnicowaną, kategorię stanowią imigranci, którzy przybyli do Poznania ze względów rodzinnych (np. małżeństwa mieszane), jako wolontariusze do pracy w organizacjach pozarządowych czy wyznaniowych, a także osoby, które pojawiły się tu w celach towarzyskich lub z innych, bardzo zindywidualizowanych powodów, jak np. potrzeba podróżowania i poznawania nowych ludzi (Bloch 2012).

W Poznaniu nie przebywają imigranci o statusie uchodźców, co najprawdopodobniej wynika z faktu lokalizacji ośrodków recepcyjnych we wschodniej Polsce.

Imigranci są grupą mało zauważalną $\mathrm{w}$ wielkomiejskiej przestrzeni Poznania. Wynika to zarówno $\mathrm{z}$ ich niskiej liczebności (nie więcej niż 2\% mieszkańców miasta), jak i z wielu innych czynników. Należy do nich zaliczyć zróżnicowanie wewnętrzne tej grupy i wynikające stąd funkcjonowanie w ramach autonomicznych i zazwyczaj mało spójnych wewnętrznie środowisk. Poza miejscami pracy i nauki imigranci funkcjonują $\mathrm{w}$ diasporze, a ich 
nieliczne enklawy - skupiska mieszkalne (np. dom studencki Uniwersytetu Medycznego czy wielorodzinne domostwa romskie) - są odizolowane od pozostałej przestrzeni miejskiej tego typu. Trudno w Poznaniu znaleźć ogólnodostępne miejsca, w których imigranci trwale zaznaczają swoją obecność. W szczególności dotyczy do grup, które z różnych względów można określić jako "trudno dostępne” (np. Romów z Rumunii oraz imigrantów pracujących w tzw. szarej strefie usług).

Większość instytucji biznesowych, towarzyskich, wyznaniowych i innych, które zakładają lub w ramach których realizują się imigranci, ma charakter zamknięty - Polacy nie mają do nich dostępu lub jest on znacząco reglamentowany. Te formy „zrzeszania się” imigrantów przybierają różne postaci.

Pierwszy typ instytucji, często nieformalnych grup towarzyskich podzielonych na sekcje męskie i żeńskie, ukierunkowany jest na integrację imigrantów legitymujących się wspólnym pochodzeniem etnicznym/narodowym, posługujących się tym samym językiem ojczystym ${ }^{7}$.

Drugi typ instytucji to organizacje (kluby) integrujące cudzoziemców pochodzących z różnych krajów, którzy komunikują się w języku angielskim ${ }^{8}$. Przynależność do nich umożliwia imigrantom spotykanie się z osobami, które znalazły się w analogicznej sytuacji życiowej, wzajemne wsparcie i wymianę doświadczeń, zawieranie znajomości i włączenie się do kręgu towarzyskiego bez konieczności znajomości języka polskiego.

Kolejnym, trzecim, typem instytucji są organizacje akademickie samorządowe - filie instytucji międzynarodowych lub autonomiczne samorządy „narodowe", filie polskich stowarzyszeń i inne9. Ich podstawowym celem

7 Zetknęliśmy się z takimi grupami, jak np. Japanese group, French group czy Dutch group. Specyficzną podgrupę $\mathrm{w}$ ramach omawianego typu tworzą organizacje biznesowe, np. Polsko-Niemieckie Koło Gospodarcze, Netherland-Polish Business Club oraz Scandinavian-Polish Chambers of Commerce, które łączą aktywność zawodową z życiem towarzyskim i promowaniem kultur narodowych.

8 Mowa tu o instytucjach zakładanych przez osoby pracujące $\mathrm{w}$ wielkich korporacjach oraz ich żony, np. liczący 50 kobiet i działający od czternastu lat Poznań International Ladies Club, klub dla mężczyzn - International Men's Club, a także wiele mniejszych organizacji, często będących sekcjami wyżej wymienionych instytucji: Toastmasters, parent-teacher organizations, grupy sportowo-rekreacyjne (joga, nordic walking), klub filmowy, klub książki czy koło artystyczne (zob. Schmidt, Sydow 2012: 88-90).

9 Np. European Medical Student Association (EMSA), American Student Government, Norwegian Student Government, Poznan Taiwanese Student Government czy North American Student Government. W Poznaniu aktywnie działa też Klub Studentów Polonijnych przy wielkopolskim oddziale Wspólnoty Polskiej. Zrzesza on cudzoziemców posiadających Kartę Polaka, jednak w praktyce klub ten jest bardziej platformą integracji studentów rosyjskojęzycznych z krajów byłego Związku Sowieckiego aniżeli organizacją polonijną (zob. Bloch, Pakieła, Przepiera, Stanisz 2012: 164-166, 188-196). 
jest zaspokajanie potrzeb studentów i pomaganie im w rozwiązywaniu bieżących problemów, nie tylko tych związanych ze studiowaniem. Ponadto instytucje te zajmują się organizowaniem imprez promujących kultury narodowe.

Czwarty typ instytucji ma profil wyznaniowy ${ }^{10}$. Misyjny charakter tych organizacji, czego wyrazem są otwarte spotkania "modlitewno-formacyjne", umożliwił wgląd $\mathrm{w}$ ich działalność i rozpoznanie liderów grup oraz wyznawców będących imigrantami. $Z$ ich oferty korzystają dość małe, liczące od kilku do kilkudziesięciu osób, grupy cudzoziemców, których skład zmienia się w związku z tymczasowością ich pobytu w Poznaniu.

Każda $\mathrm{z}$ tych instytucji wyznaniowych ma inny zasięg oddziaływania poza granicami Polski i w związku z tym w poszczególnych świątyniach można spotkać imigrantów pochodzących z innych krajów i części świata, np. Ukraińcy dominują w cerkwi, cudzoziemcy ze świata arabskiego w meczecie, a Afrykanie w kościele zielonoświątkowców. Wyjątkiem jest ekumeniczny Poznań International Church, wyróżniający się najbardziej zróżnicowanym składem etnicznym wyznawców. Na podstawie dotychczasowych ustaleń można stwierdzić, że środowiskami imigranckimi, których przedstawiciele najliczniej uczestniczą $\mathrm{w}$ praktykach religijnych, są studenci oraz cudzoziemcy legitymujący się bardzo długim stażem pobytowym w Poznaniu. Na tle innych instytucji placówki omawianego typu jawią się jako szeroka platforma kontaktów imigrantów z Polakami.

W ramach wszystkich wyżej opisanych instytucji cudzoziemcy tworzą homogeniczne powiązania społeczne w obrębie pojedynczych grup. Najwięcej form instytucjonalizacji o charakterze ekskluzywnym można zaobserwować w środowisku tzw. imigrantów uprzywilejowanych, zwłaszcza pracowników wielkich korporacji i ich rodzin. Na tym tle uderza brak takich form zorganizowania w środowisku profesjonalistów w sektorze edukacji.

Poznańscy cudzoziemcy traktują swój pobyt w Polsce jako tymczasowy. Ich migracje mają charakter cyrkulacyjny, często sezonowy, w niektórych przypadkach również wahadłowy. Nawet osoby, które przebywają tu od wielu lat, deklarują elastyczność decyzji o pozostaniu w Poznaniu, uzależniają ją od sytuacji ekonomicznej i rynku pracy w Polsce, kraju pochodzenia oraz w innych częściach świata. Zdecydowana większość imigrantów nie

${ }^{10}$ Najważniejszymi z nich są: Poznań International Church (placówka ekumeniczna prowadzona przez baptystów), Muzułmańskie Centrum Kulturalno-Oświatowe, The Way Church LWM (zielonoświątkowcy), Kościół Jezusa Chrystusa Świętych w Dniach Ostatnich (mormoni), Cerkiew Greckokatolicka, Cerkiew Prawosławna, Church of Nazarene (metodyści), Adwentyści Dnia Siódmego oraz Świadkowie Jehowy (zob. Chwieduk 2012; Gust 2013; Minakowski 2013). 
dąży do integracji wyrażającej się nabyciem obywatelstwa kraju przyjmującego, ale zadowala się posiadaniem zezwolenia na osiedlenie. Postawa ta cechuje zarówno osoby z krótszym stażem migracyjnym, jak i cudzoziemców rezydujących w naszym kraju od kilkunastu lub więcej lat. Towarzyszy temu niski poziom oczekiwań wobec społeczeństwa przyjmującego i brak postaw o charakterze roszczeniowym, a także małe zainteresowanie sprawami lokalnymi i krajowymi państwa przyjmującego, niechęć do zaangażowanego uczestnictwa $\mathrm{w}$ życiu publicznym. Opisany stan rzeczy wynika między innymi $\mathrm{z}$ tego, że $\mathrm{w}$ Poznaniu mamy do czynienia $\mathrm{z}$ dominacją tzw. imigrantów uprzywilejowanych, w przypadku których można mówić bardziej o niezbędnych strategiach adaptacyjnych aniżeli dążeniu do integracji ze społeczeństwem przyjmującym. Podobną postawę wykazują mniejsze grupy imigrantów (np. Romowie z Rumunii czy misjonarze z niektórych wspólnot wyznaniowych), dążące do zachowania odrębności i względnej izolacji, a kontakty z Polakami ograniczające do ściśle reglamentowanych obszarów. Innym istotnym czynnikiem utrudniającym adaptację i integrację jest bariera językowa, związana z trudnością języka polskiego dla obcokrajowców oraz niskimi motywacjami do jego nauki, wynikającymi z zakładanej tymczasowości pobytu w Polsce.

W związku z tym można zaryzykować tezę, że w wielkomiejskiej przestrzeni Poznania imigranci funkcjonują niejako „obok” społeczeństwa przyjmującego. Ten stan rzeczy utrwala brak w Polsce spójnej polityki integracyjnej na poziomie krajowym i lokalnym, która pomagałaby imigrantom efektywniej zaistnieć w nowym otoczeniu społeczno-kulturowym, a zarazem zachęcić ich do trwalszego związania się z obecnym miejscem pobytu11.

\section{BIBLIOGRAFIA}

Adamowicz A., Bloch N., Kochaniewicz A., Rydzewski R. (2012), Imigranci w sektorze handlu i ustug, [w:] Migracje a heterogeniczność kulturowa. Na podstawie badań antropologicznych w Poznaniu, red. M. Buchowski, J. Schmidt, Nauka i Innowacje, Poznań.

${ }^{11}$ W chwili obecnej Centrum Badań Migracyjnych UAM realizuje pionierski w skali kraju projekt badawczy finansowany przez Unię Europejską: Aktywni imigranci na lokalnym rynku pracy. Projekt wspótpracy polsko-niemieckiej. Realizacja tego przedsięwzięcia polega między innymi na pracy antropologów w charakterze streetworkerów w poznańskich środowiskach imigranckich, prowadzeniu stałego biura konsultacyjnego, w którym odbywają się szkolenia dla imigrantów oraz dyskusje z udziałem antropologów, prawników, ekonomistów, przedstawicieli świata biznesu oraz samych imigrantów. Tego typu projekty, wdrażane $w$ znacznie szerszym zakresie w innych krajach europejskich (Jonda 2012), ukierunkowane są na pomoc cudzoziemcom $\mathrm{w}$ procesie ich adaptacji życiowej $\mathrm{w}$ nowym miejscu osiedlenia, optymalizację integracji imigrantów na lokalnych rynkach pracy, ułatwienie im podnoszenia kwalifikacji zawodowych, a także rozbudowanie sieci ich powiązań ze stałymi mieszkańcami. 
Alscher S. (2008), Country Profile - Poland, „Focus Migration” no. 2 (January).

Bloch N. (2012), Imigranci „z mitości” i wolontariusze, [w:] Migracje a heterogeniczność kulturowa. Na podstawie badań antropologicznych w Poznaniu, red. M. Buchowski, J. Schmidt, Nauka i Innowacje, Poznań.

Bloch N., Czerniejewska I., Main I. (2012), Zjawisko imigracji do Poznania w świetle źródeł zastanych, [w:] Migracje a heterogeniczność kulturowa. Na podstawie badań antropologicznych w Poznaniu, red. M. Buchowski, J. Schmidt, Nauka i Innowacje, Poznań.

Bloch N., Pakieła A., Przepiera Ż., Stanisz A. (2012), Imigranci - studenci, [w:] Migracje a heterogeniczność kulturowa. Na podstawie badań antropologicznych w Poznaniu, red. M. Buchowski, J. Schmidt, Nauka i Innowacje, Poznań.

Buchowski M., Schmidt J., red. (2012), Migracje a heterogeniczność kulturowa. Na podstawie badań antropologicznych w Poznaniu, Nauka i Innowacje, Poznań.

Chwieduk A. (2012), Imigranci z grup "trudno dostępnych”, [w:] Migracje a heterogeniczność kulturowa. Na podstawie badań antropologicznych w Poznaniu, red. M. Buchowski, J. Schmidt, Nauka i Innowacje, Poznań.

Czerniejewska I. (2010), Młodzi cudzoziemcy w poznańskich szkołach, „Przegląd Wielkopolski" nr 4(90).

Faist T. (2010), O transnarodowym przetwarzaniu granic, przestrzeni i mechanizmów społecznych, [w:] Mozaiki przestrzeni transnarodowych. Teorie - metody - zjawiska, red. Ł. Krzyżowski, S. Urbańska, Nomos, Kraków.

Górny A., Grabowska-Lusińska I., Lesińska M., Okólski M., red. (2010), Transformacja nieoczywista. Polska jako kraj imigracji, Wydawnictwa Uniwersytetu Warszawskiego, Warszawa.

Grzymała-Kazłowska A., red. (2008), Między jednościq a wielością. Integracja odmiennych grup i kategorii imigrantów w Polsce, Ośrodek Badań nad Migracjami WNE UW, Warszawa.

Hannerz U. (2006), Powiazania transnarodowe. Kultura, ludzie, miejsca, Wydawnictwo Uniwersytetu Jagiellońskiego, Kraków.

Jonda B. (2012), Willkommenskultur - zmiana paradygmatu w polityce imigracyjnej Niemiec? [w:] Imigranci. Między izolacja a integracja, red. M. Buchowski, J. Schmidt, Nauka i Innowacje, Poznań.

Kaczmarczyk P. (2011), Polska jako kraj emigracji i imigracji, [w:] Mobilność i migracje w dobie transformacji. Wyzwania metodologiczne, red. P. Kaczmarczyk, Wydawnictwo Naukowe Scholar, Warszawa.

Mirgos K. (2010), „Hiszpański” Poznań, „Przegląd Wielkopolski” nr 4(90).

Schmidt J., Sydow K. (2012), Imigranci - profesjonaliści w sektorze biznesu, [w:] Migracje a heterogeniczność kulturowa. Na podstawie badań antropologicznych w Poznaniu, red. M. Buchowski, J. Schmidt, Nauka i Innowacje, Poznań.

Wspótpraca droga do integracji. Zalecenia dla polityki integracyjnej Polski (2012), MSW, Warszawa.

\section{Źródła internetowe}

http://tuudi.net/wp-content/uploads/2012/08/lu_raport_z_wynikow_NSP2011.pdf [dostęp: 1.10.2013].

http://wiadomosci.gazeta.pl/wiadomosci/1,114871,13828434,Pod_sad_za_atak_na_bar_ Kurdow_w_Opolu.html [dostęp: 1.10.2013]. 
http:/ / wiadomosci.onet.pl/bialystok/napad-na-mlodego-czeczena-w-autobusie-ruszaproces/5et3z [dostęp: 30.10.2013].

Stryjakiewicz T., Kaczmarek T., Łodyga B., Marcinowicz D., Męczyński M., Parysek J., Stachowiak K. (2009), The attractiveness of the Poznan metropolitan region for the development of the creative knowledge sector. The view of transnational migrants, ACRA report 7.8, University of Amsterdam, Amsterdam, http://dare.uva.nl/document/189079 [dostęp: 1.02.2014]

\section{Źródła niepublikowane}

Gust K. (2013), Imigranci z krajów arabskich jako przykład społeczności muzutmańskiej w Poznaniu, praca magisterska napisana pod kierunkiem prof. UAM dr. hab. G. Pełczyńskiego w Instytucie Etnologii i Antropologii Kulturowej UAM.

Jur K. (2012), Powiązania transnarodowe imigrantów na przykładzie wykwalifikowanych pracowników sektora edukacji w Poznaniu, praca magisterska napisana pod kierunkiem prof. UAM dr. hab. J. Schmidta w Instytucie Etnologii i Antropologii Kulturowej UAM.

Kochaniewicz A. (2013), Imigranci zarobkowi w sektorze ustugowo-gastronomicznym w Poznaniu: strategie migracyjne $i$ integracyjne, praca magisterska napisana pod kierunkiem prof. dr. hab. M. Buchowskiego w Instytucie Etnologii i Antropologii Kulturowej UAM.

Minakowski K. (2013), Misjonarze z Kościoła Jezusa Chrystusa Świętych w Dniach Ostatnich ich praca i relacje z Polakami, praca magisterska napisana pod kierunkiem prof. UAM dr. hab. J. Schmidta w Instytucie Etnologii i Antropologii Kulturowej UAM. 